\title{
Suggestions on the Construction of Harmonious Campus
}

\author{
Gao Le \\ Jilin Agricultural University, Changchun.China \\ E-mail: ruoyinle2001@163.com
}

Keywords: the Harmonious Campus; Scientific Outlook on Development; Construction of colleges

\begin{abstract}
It is an important practice of constructing the harmonious campus and carrying out the "Scientific Outlook of Development", which is regarded as one of the important measures implemented by The Central Committee of China's Communist Party for the strategy of "rejuvenating China through science and education", and for the essential condition of "realizing China's Dream". From the perspective of "Scientific Outlook of Development", the paper explains the importance of constructing harmonious campus in colleges and universities, analyzes the unfavorable factors and the effective measures in order to create a sustainable environment for teaching and scientific research.
\end{abstract}

\section{Introduction}

The construction of harmonious campus can not be without the essential part of constructing harmonious society. To build a harmonious campus is an arduous and complex systematic project, an eternal theme with long period, which needs the unremitting efforts and fully participation of all teachers and students. To develop and built colleges and universities, it is the fundamental way of constructing harmonious campus, in which the scientific outlook on development should be taken as a guide to replace the traditional concepts, and the focus should be on construction and development. The harmony is enhanced through development, promoted by reform, sought in fairness and guaranteed under stability, to push forward the variety of all the causes in campus.

\section{Significance of Constructing Harmonious Campus}

Xi Jin-ping, China's president, pointed out in the 20th national work conference about the party's construction of colleges and universities, that the important of education is to educate and foster young generation in universities and colleges campus, that university and college campus is a significant place where young generation should be armed with the core value of socialism. Harmonious campus is an important aspect of realizing the social harmony.

The necessity of constructing a harmonious campus. At present, with the deepening of globalization, the international division of labor makes the international trade and other economic exchanges closer and closer. which indicated that all countries in the world are deepening the globalization strategy to guarantee their place in globalization background. In order to win competition's victory in the context of globalization, it is necessary to attach importance to education and scientific research. At the same time, China's socialist construction has changed from the simplicity of cargo processing to the channels of research, innovation and marketing. 
The construction of a harmonious campus contributes to safeguard and promote the reform of university education. University education reform will inevitably encounter setbacks on the way forward, damage a part of people's interest, and there will inevitably be the phenomenon that some people give it up in the halfway. However, a harmonious campus can make up the problems which appeared in the process of reform in colleges and universities, and it is mainly related to the core of harmony. The construction of a harmonious campus, is the important power for competent colleges and universities towards the world, and is the important guarantee to build up the soft environment of freedom, equality, and gumption in colleges and universities. Through the construction of a harmonious campus, realize another leap of universities and colleges, and put the revolution of colleges and universities to the end.

\section{Problems of Constructing a Harmonious Campus}

The construction of a harmonious campus is a long-term systematic project, involving every aspect question, summarized as follows:

Above all the concept of tool value is not adapt to the construction of a harmonious campus. The useful tool means that China's education administrative department takes the college education as a tool to teach and instill ideology and values. Moral education curriculum setup and determine the education content of examination and approval by the central committee of the political discussion, and then the enactment, comply with them. This useful tool as the guarantee of our party to cultivate socialist successor has practical significance and long-term value, but too much attention to the teaching of ideology and instilling, certainly will among students, a revulsion appeal. To build a harmonious campus is to be truly the unity of the students and school, university education and the development of the national reunification.

Instrumental value, refers to the portion of our colleges teaching courses and teachers instill values as to keep their jobs, regardless of the teaching and instilling values whether they accept or not and understand ,and it seems that it is merely a job to teach after they complete the task.

Secondly: Influence of false market concept on Harmonious Campus

Market economy emphasizes the material interests, to pursuit the maximum profit, and the interest orientation of the market economy is hotbeds of the money worship and hedonism. University is a microcosm of society employment is the most important thing in those college students who are in the tide of economic globalization, Facing reality, quiet a number of college students are effected by utilitarian values for most and money worship, hedonism life view, they apply exchange at equal value to moral, emotion, consider the fame, fortune as an official standard of happiness in life and pleasure and luxury living are the biggest goal.

Last but not the least: Moral crisis hindered the construction of harmonious campus

With the globalization of value diversity and lead to moral crisis and faith crisis in social transition, is also a challenge to the current Harmonious campus construction. Morality is the foundation of constructing harmonious campus in Colleges .people will lose their worship, harmonious campus construction will lose their reputation if the high schools without moral restraint. 


\section{Suggestion on the construction of a harmonious campus}

Insisting on scientific development view is the most important thing when constructing a harmonious campus, in accordance with the requirements of the scientific development concept Colleges and universities practice the concept of building a harmonious campus. The key point of the scientific development concept lie in the last word "development". To build a harmonious campus is to better promote the development of the school, to accelerate the speed of the development of higher education in our country and to implement the strategy of developing the country though science and education. Colleges and universities should not only make overall plans and take all factors into consideration but also keep pace with the times during the construction of a harmonious campus, on the one hand ,Colleges and universities should consider the historical background of the this era, on the other hand, they need to guarantee universities' normal teaching and scientific research tasks, give consideration to the profit of schools, teachers, students. At the same time, as the forefront of thought, science and technology of the society, colleges and universities should get rid of old system and policy timely, do not the follow the old way at ease , they must have the innovation consciousness, constantly push college education to a new height.

Set up correct concept of development in colleges and universities; absorb concepts of globalization, marketing and diversification into the construction of a harmonious campus. The socalled harmony is that colleges and universities can share convenience of the globalization, and can through the market to promote their own development, realize the docking with the market. In the meantime, Colleges and universities should have the tolerance toward different cultures, different faiths form diversified cultures. To build a harmonious campus, the campus cannot be closed up, universities should stand in the Angle of The Times development, combined with international and domestic situation, straighten out some of the obstacles to a harmonious campus construction, actively seek breakthrough, adjustment which is not harmonious.

Harmonious campus requires all the teachers and students to participate. We need to go in accordance with the concept of harmony to slowly change disharmonious campus culture and ideology, the school is our common homeland, to build a harmonious campus needs all the teachers to abandon self-interest personal desires, to set up one for all, all for my idea. Colleges and universities should establish incentive mechanism, increase the cost of ideological construction of campus culture, establish the concept of service for students and teachers, more conducive to the construction of harmonious campus' activities, carry out rich and colorful campus life, pay attention to students' academic training and practical ability, establish benign contact with society, let the students to know the society, deepen their love to the society.

The construction of a harmonious campus is a long-term task that requires colleges and universities according to their own actual situation, continuing to explore. Colleges and universities should take scientific outlook on development as guidance, combined with the problems in the process of development, summarizes the methods and measures of building a harmonious campus to push the construction of a harmonious campus to a new height.

\section{Summary}

This paper thinks that harmonious campus construction is the foundation of building a harmonious society, and whether the campus construction can put the scientific outlook on development into 
practice or not will somehow influence the nation's future destiny. Today, in the economic globalization background, universities should do the teaching reform continuously and strengthen the construction of a harmonious campus so that students can hold global horizon. In view of the current problems which exist in the construction of harmonious campus in colleges, such as unscientific tool value concept, the wrong market concept and the hindrance of moral crisis, we should put forward the following countermeasures:

1. Set up correct concept of development in colleges and universities, and combine globalization, marketing and diversification with the construction of a harmonious campus.

2. Building a harmonious campus needs all the teachers and students' participation, which means everyone, makes slow changes towards unharmonious culture and thought according to the concept of harmony. School is our common homeland, building a harmonious campus needs teachers not only abandon selfish personal desires, but also set up "one for all, all for one” idea.

3. The construction of a harmonious campus is a long-term task. Colleges and universities could explore it continuously according to their own actual situation.

\section{References}

[1]Wu, F. Based on the college campus culture construction research of innovative personnel training, Journal of Nanchang institute of education, (2013), p.59-60

[2] Martin T, Xu D, \&Lian, J.J. From elite to mass to the reflection of the popularization of Higher Education: modern society, higher education after World War II the morphology and phase of the , University of Education Science, (2009), p.5-24

[3] Wang, N.N. The study of implementation of quality education to promote all-round development of students, Journal of new western (theory), (2013), p.113-115

[4] Zhang,G.L. Several problems of the construction of a harmonious campus need to focus on, Journal of Shanxi Datong University (Social Science Edition), (2008), p. 83-85

[5] Mao, S. F.Social management, the harmonious campus and the talent training" theory seminar word, Theoretical front in higher education, (2011) p. 65

[6] Wang, T..On the harmonious campus construction in Local Universities, Local University Modern Education Forum (version management), (2010) p. 28-29

[7] Liang, C. From the perspective of the construction of harmonious university campus, Journal of Northeast Normal University of scientific outlook on Development (Philosophy and Social Sciences edition), (2009), p. 86-92 